\title{
FERTILIZER NITROGEN IN SOIL
}

\author{
ARMi KaIla \\ University of Helsinki, Department of Agricultural Chemistry
}

Pentti Hänninen

Agricultural Research Centre, Central Finland Agricultural Experiment Station

Received May 8, 1961

Soluble nitrogen fertilizers are usually applied as a surface dressing. It is supposed that the salts are rapidly dissolved by the soil moisture and carried downwards to the layers where the plant roots are able to take up their ions. Particularly the nitrate ion is assumed to be very easily movable in the soil.

This, however, may not always be the case. Cunningham and Cooke (1) found that nitrate was not easily removed from the surface layer of a heavy soil by summer rainfalls sufficient to be detectable in drainage. GASSER (2) showed that leaching of nitrate in a light soil was effective only in prolonged wet periods. Some observations in Finland also indicate that in dry summers a large part of the nitrate nitrogen applied as a surface dressing may remain in the top inch (6).

In order to study this problem more thoroughly under the conditions of arable land in Finland, samples were regularly collected from field trials in which calcium nitrate or ammonium nitrate limestone were applied at various rates. The distribution of ammonium and nitrate nitrogen was followed through two growing periods. In one experiment, also the distribution of fertilizer nitrogen in a non-cropped soil was studied.

\section{Material and methods}

The field trials were carried out in 1959 and 1960 in Viikki, the experimental farm of Helsinki University, and in the experimental fields of Agricultural Research Centre in Central Finland. The experimental crop was oats. The yield results are reported elsewhere (4).

In 1959, in the trials of V 1 and V 2 in Viikki, and $\mathrm{K} 1$ and $\mathrm{K} 2$ in Central Finland, ammonium nitrate limestone or calcium nitrate were applied as the surface dressing at rates corresponding to 0,25 , and $50 \mathrm{~kg} / \mathrm{ha}$ of nitrogen. In 1960, in trials V 4 in Viikki and $\mathrm{K} 5$ in central Finland heavier dressings were used: 75 and $100 \mathrm{~kg} / \mathrm{ha}$ of nitrogen. In trial V 4 the treatments were applied to cropped and non-cropped plots. 
The soil samples were collected every fourteenth day starting about one week after the fertilizers had been applied to the seeded plots. A special core sampler (3) was employed which allows rapid sampling of each successive layer of one inch down to 4 inches. An additional sample from 4 inches to about 6 inches was taken with another auger. Further samples were taken for moisture determination in each trial.

In order to avoid disturbing of the stands to be harvested, a special sampling area of $0.4 \mathrm{~m}$ breadth was reserved in each plot. At each sampling, ten cores were taken per plot, and samples from the same layer of the plot were bulked. The holes were filled with soil and a top layer of sand in order to prevent a new sampling from the same place. The samples were collected systematically, with a distance of 0.8 meter between the spots.

Since it was not possible to arrange the analyzing of the soil samples immediately after collecting. the samples were air-dried at room temperature and ground. The four replicate samples were separately analyzed.

Ammonium nitrogen and nitrate nitrogen were extracted with $0.5 \mathrm{~N} \mathrm{~K}_{2} \mathrm{SO}_{4}$ in the ratio of $1: 10$. The time of extraction was 2 hours. The ammonium nitrogen was determined from an aliquote of the filtrate by steam distillation into boric acid according to the procedure recommended by LYNDERSEN and OPEM (5). The nitrate nitrogen was determined from the filtrate by the phenol disulphonic acid method.

The ammonium fixing capacity of the experimental soils was determined by an unpublished method proposed by Prof. Dr. P. SснаснтsснавEL. $5 \mathrm{~g}$ of soil was mixed with $50 \mathrm{ml}$ of $\mathrm{N} \mathrm{NH}_{4} \mathrm{Cl}$ in a decanter and let stand for one day with occasional stirring. The clear solution was decanted and the soil washed first with $\mathrm{N} \mathrm{CaCl}_{2}$ and then four times with $0.2 \mathrm{~N} \mathrm{CaCl}_{2}$. Finally it was twice washed with methylated spirits, dried at $105^{\circ} \mathrm{C}$, and ground. $4.0 \mathrm{~g}$ of the treated sample and $4.0 \mathrm{~g}$ of an untreated one were boiled in $20 \mathrm{ml}$ of concentrated $\mathrm{H}_{2} \mathrm{SO}_{4}$ for three hours, and the ammonium nitrogen distilled into boric acid. The difference between the amounts of ammonium nitrogen in the treated and untreated samples is presumed to represent the ammonium fixing capacity of the soil.

\section{Experimental soils}

Some characteristics of the experimental soils are recorded in Table 1. The trials in Central Finland, $\mathrm{K} 1, \mathrm{~K} 2$, and $\mathrm{K} 5$ were on silt or loam soils low in organic matter and only slightly acid. The clay content of the experimental soils in Viikki, in trials V 1, V 2, and V 4, is markedly higher as is also the case with content of organic matter in these soils. The silt clay soils of trials V 1 and V 4 are acid, the fine sand clay of trial V 2 is less acid and somewhat lower in organic matter than the other two soils in Viikki.

Table 1. Soils

\begin{tabular}{|c|c|c|c|c|c|c|c|}
\hline \multirow[b]{2}{*}{ Trial } & \multirow[b]{2}{*}{$\mathrm{pH}$} & \multirow{2}{*}{$\begin{array}{c}\text { Org. C } \\
\%\end{array}$} & \multirow{2}{*}{$\begin{array}{l}\text { Weight } \\
\text { of } \\
\text { volume }\end{array}$} & \multicolumn{4}{|c|}{ Mechanical Analysis, \% } \\
\hline & & & & $\begin{array}{c}\text { Clay } \\
<0.002 \mathrm{~mm}\end{array}$ & $\begin{array}{c}\text { Silt } \\
0.002-0.02 \mathrm{~mm}\end{array}$ & $\begin{array}{l}\text { Fine sand } \\
0.02-0.2 \mathrm{~mm}\end{array}$ & $\begin{array}{l}\text { Sand } \\
0.2-2 \mathrm{~mm}\end{array}$ \\
\hline K 1 & 6.2 & 2.5 & 1.21 & 21 & 62 & 16 & 1 \\
\hline $\mathrm{K} 2$ & 5.9 & 2.2 & 1.22 & 10 & 58 & 30 & 2 \\
\hline K 5 & 5.7 & 2.5 & 1.19 & 18 & 53 & 26 & 3 \\
\hline V 1 & 5.1 & 6.4 & 0.94 & 43 & 30 & 25 & 2 \\
\hline V 2 & 5.6 & 4.6 & 1.02 & 40 & 22 & 31 & 7 \\
\hline V 4 & 5.3 & 5.4 & 0.94 & 47 & 28 & 22 & 3 \\
\hline
\end{tabular}




\section{Meteorological conditions}

Owing to the early spring in 1959 sowing could occur in Viikki already in the end of April, and in Central Finland in the middle of May. In 1960 sowing took place in the middle of May in Viikki and in the end of May in Central Finland.

The amount and quality of rain plays an important role in the removal and changes of the fertilizer nitrogen in soil. In order to get an idea of the precipitation conditions in the experimental periods the amount of rain obtained and the number of rainy days between the sampling dates are recorded from date of sowing.

Precipitation in 1959

in Viikki

in Central Finland

Precipitation in 1960 in Viikki

in Central Finland

$$
\begin{aligned}
& \text { April 25 - May } 11 \\
& \text { May } 12 \text { - May } 25 \\
& \text { May 26- June } 8 \\
& \text { June } 9 \text { - June } 22 \\
& \text { June 23 - July } 6
\end{aligned}
$$

$$
\begin{aligned}
& \text { May } 20-\text { May } 28 \\
& \text { May } 29-\text { June } 11 \\
& \text { June } 12-\text { June } 25 \\
& \text { June } 26 \text { - July } 9
\end{aligned}
$$

$$
\begin{aligned}
& \text { May } 16 \text { - May } 31 \\
& \text { June } 1-\text { June } 12 \\
& \text { June } 14-\text { June } 27 \\
& \text { June } 28 \text { - July } 12 \\
& \text { May } 23 \text { - June } 9 \\
& \text { June } 10 \text { - June } 23 \\
& \text { June } 24 \text { - July } 7
\end{aligned}
$$

\begin{tabular}{|c|c|c|c|c|}
\hline & $\mathrm{N}$ & $2 \mathrm{~N}$ & $3 \mathrm{~N}$ & $4 \mathrm{~N}$ \\
\hline & $25 \mathrm{~kg} / \mathrm{ha}$ & $50 \mathrm{~kg} / \mathrm{ha}$ & $75 \mathrm{~kg} / \mathrm{ha}$ & $100 \mathrm{~kg} / \mathrm{ha}$ \\
\hline K 1, K $2, \quad$ K 5 & 80 ppm & $160 \mathrm{ppm}$ & $240 \mathrm{ppm}$ & 320 ppm \\
\hline $\mathrm{V} 1, \quad \mathrm{~V}_{2} 2, \mathrm{~V}_{4}$ & 100 & 200 & 300 & 400 \\
\hline
\end{tabular}

$\begin{array}{rc}\begin{array}{c}\text { Rainfall } \\ \text { in mm }\end{array} & \begin{array}{c}\text { No. of } \\ \text { rainy days }\end{array} \\ 17 & 4 \\ 4 & 3 \\ 23 & 7 \\ 11 & 7 \\ 62 & 6 \\ & \\ 15 & 3 \\ 17 & 4 \\ 14 & 7 \\ 76 & 5\end{array}$

$\begin{array}{rr}0 & 4 \\ 7 & 12 \\ 55 & 10 \\ 36 & \end{array}$

$\begin{array}{ll}19 & 4 \\ 48 & 9 \\ 29 & 7\end{array}$

In 1959 the first heavy rainfalls occurred at the beginning of July, while in 1960 there was a fairly wet period in the middle of June. Owing to the difference in the date of sowing in Viikki and in Central Finland, the trials in the former place had a longer relatively dry period than the trials in the latter place.

\section{Distribution of ammonium and nitrate nitrogen in the experimental soils}

The amounts of nitrogen applied as surface dressing in these trials approximately correspond to the following quantities of nitrogen calculated as $\mathrm{ppm}$. in a layer of the depth of one inch:

One half of the nitrogen in ammonium nitrate limestone is ammonium nitrogen, the other half is nitrate nitrogen. Also in calcium nitrate a small part, usually about $1 \%$ of the nitrogen, exists in the form of ammonium ions. 
Table 2. $\mathrm{NH}_{4}-\mathrm{N}$ and $\mathrm{NO}_{3}-\mathrm{N}$ in the soil of trial $\mathrm{K} 1$ treated with ammonium nitrate limestone

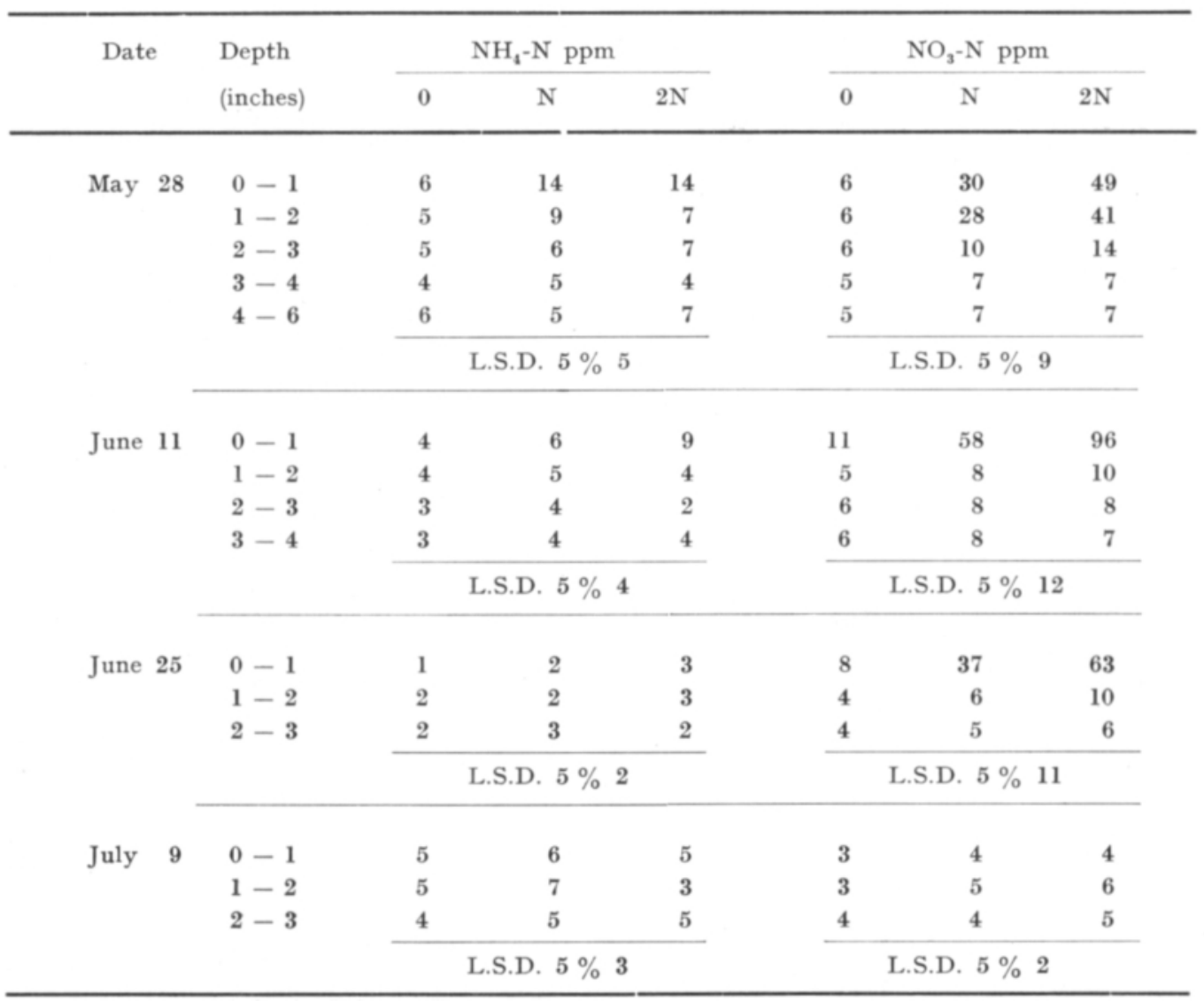

In Tables 2 and 3 the analytical results are reported of the soils in trials $\mathrm{K} 1$ and $\mathrm{K} 2$ treated with ammonium nitrate limestone. As could be expected, the effect of the fertilizer on the ammonium nitrogen content of the soil is observable only in the surface inch of both trials. The nitrate nitrogen content of the treated soils is higher than that of the untreated ones down to two inches at the sampling in the end of May. Later on, the plants probably take up nitrogen from this second inch but are not able to utilize the nitrogen in the fairly dry top inch: in June the moisture of the top inch soil was from 20 to 30 per cent less than that in the second inch soil. The increase in the nitrate nitrogen content of the top inch in both trials in the period from May 28 to June 11 may be explained as a result of nitrification or as the removal of nitrate ions up from the second layer. First after the heavy rains in the beginning of July the surface soil was also depleted. No accumulation of nitrogen in the deeper layers could be observed.

There is one interesting difference between the analytical data of these two trials. The amounts of ammonium nitrogen extracted from the first samples of trial $\mathrm{K} 1$ are low as compared with those of trial $\mathrm{K} 2$. This fact may be connected with the ammonium fixing capacity of these soils. 
Table 3. $\mathrm{NH}_{4}-\mathrm{N}$ and $\mathrm{NO}_{3}-\mathrm{N}$ in the soil of trial $\mathrm{K} 2$ treated with ammonium nitrate limestone

\begin{tabular}{|c|c|c|c|c|c|c|c|}
\hline \multirow[b]{2}{*}{ Date } & \multirow{2}{*}{$\begin{array}{l}\text { Depth } \\
\text { (inches) }\end{array}$} & \multicolumn{3}{|c|}{$\mathrm{NH}_{4}-\mathrm{N}$ ppm } & \multicolumn{3}{|c|}{$\mathrm{NO}_{3}-\mathrm{N}$ ppm } \\
\hline & & 0 & $\mathbf{N}$ & $2 \mathrm{~N}$ & 0 & $\mathbf{N}$ & $2 \mathrm{~N}$ \\
\hline \multirow[t]{4}{*}{ May } & $0-1$ & 5 & 20 & 42 & 11 & 36 & 62 \\
\hline & $1-2$ & 3 & 5 & 12 & 9 & 20 & 29 \\
\hline & $2-3$ & 3 & 5 & 4 & 8 & 11 & 12 \\
\hline & $3-4$ & 3 & 6 & 6 & 8 & 9 & 8 \\
\hline \multirow[t]{2}{*}{. } & $4-6$ & 4 & 7 & 6 & 8 & 10 & 8 \\
\hline & & \multicolumn{3}{|c|}{ L.S.D. $5 \% 9$} & \multicolumn{3}{|c|}{ L.S.D. $5 \% 12$} \\
\hline \multirow[t]{5}{*}{ June 12} & $0-1$ & 3 & 6 & 20 & 15 & 52 & 109 \\
\hline & $1-2$ & 3 & 3 & 4 & 6 & 9 & 11 \\
\hline & $2-3$ & 3 & 3 & 3 & 6 & 5 & 8 \\
\hline & $3-4$ & 3 & 4 & 3 & 6 & 6 & 7 \\
\hline & & \multicolumn{3}{|c|}{ L.S.D. $5 \% 5$} & \multicolumn{3}{|c|}{ L.S.D. $5 \% 12$} \\
\hline \multirow[t]{4}{*}{ June 26} & $0-1$ & 3 & 3 & 9 & 6 & 17 & 42 \\
\hline & $1-2$ & 3 & 2 & 3 & 4 & 5 & 6 \\
\hline & $2-3$ & 5 & 3 & 3 & 4 & 4 & 5 \\
\hline & & \multicolumn{3}{|c|}{ L.S.D. $5 \% 3$} & \multicolumn{3}{|c|}{ L.S.D. $5 \% 6$} \\
\hline \multirow[t]{4}{*}{ July 10} & $0-1$ & 2 & 5 & 7 & 4 & 4 & 4 \\
\hline & $1-2$ & 3 & 3 & 6 & 4 & 5 & 4 \\
\hline & $3-4$ & 3 & 3 & 5 & 4 & 4 & 4 \\
\hline & & \multicolumn{3}{|c|}{ L.S.D. $5 \% 4$} & \multicolumn{3}{|c|}{ L.S.D. $5 \% 1$} \\
\hline
\end{tabular}

The method employed in the present work to characterize the ammonium fixation showed that the soil of trial $\mathrm{K} 1$ had a fixation capacity of about $200 \mathrm{ppm}$ of ammonium nitrogen while the soil of trial $\mathrm{K} 2$ did not fix any ammonium nitrogen.

The data in Table 4 which show the nitrate nitrogen content of the soils of trials $\mathrm{K} 1$ and $\mathrm{K} 2$ treated with calcium nitrate, do not essentially differ from those of the former tables. The only exception is that the effect of the heavier application may be detected at first sampling also in the third layer in trial $\mathrm{K} 1$.

The results of the analyses of the trials in Viikki in 1959 are reported in Tables 5,6 and 7 . The content of ammonium nitrogen in these soils rich in organic matter is about twice as high as that in the soils of Central Finland. The application of ammonium nitrogen is demonstrated by the higher values of the top inch, only in trial V 1 the heavier dressing seems to have been able to increase the ammonium nitrogen content of the second layer. In contrast to the findings in trials $\mathrm{K} 1$ and $\mathrm{K} 2$, the ammonium nitrogen content of the top layer remains markedly high in the treated plots of trials V 1 and V 2 until sampling in July. It may be mentioned 
Table 4. $\mathrm{NO}_{3}-\mathrm{N}$ in the soils of trials $\mathrm{K} 1$ and $\mathrm{K} 2$ treated vith calcium nitrate

\begin{tabular}{|c|c|c|c|c|c|c|c|c|}
\hline \multirow{2}{*}{\multicolumn{2}{|c|}{ Date }} & \multirow{2}{*}{$\begin{array}{l}\text { Depth } \\
\text { (inches) }\end{array}$} & \multicolumn{3}{|c|}{ K 1} & \multicolumn{3}{|c|}{ K 2} \\
\hline & & & 0 & $\mathrm{~N}$ & $2 \mathrm{~N}$ & 0 & $N$ & $2 \mathrm{~N}$ \\
\hline \multirow[t]{6}{*}{ May } & $28-29$ & $0-1$ & 6 & 39 & 67 & 11 & 62 & 113 \\
\hline & & $1-2$ & 6 & 49 & 78 & 9 & 24 & 48 \\
\hline & & $2-3$ & 6 & 12 & 22 & 8 & 13 & 15 \\
\hline & & $3-4$ & 5 & 6 & 6 & 8 & 9 & 9 \\
\hline & & $4-6$ & 5 & 6 & 6 & 8 & 8 & 8 \\
\hline & & & \multicolumn{3}{|c|}{ L.S.D. $5 \% 9$} & \multicolumn{3}{|c|}{ L.S.D. $5 \% 12$} \\
\hline \multirow[t]{5}{*}{ June } & $11-12$ & $0-1$ & 11 & 70 & 138 & 15 & 74 & 120 \\
\hline & & $1-2$ & 5 & 12 & 11 & 6 & 8 & 21 \\
\hline & & $2-3$ & 6 & 8 & 9 & 6 & 6 & 9 \\
\hline & & $3-4$ & 6 & 7 & 7 & 6 & 7 & 7 \\
\hline & & & \multicolumn{3}{|c|}{ L.S.D. $5 \% 12$} & \multicolumn{3}{|c|}{ L.S.D. $5 \% 12$} \\
\hline \multirow[t]{4}{*}{ June } & $25-26$ & $0-1$ & 8 & 50 & 91 & 6 & 28 & 43 \\
\hline & & $1-2$ & 4 & 9 & 9 & 4 & 6 & 7 \\
\hline & & $2-3$ & 4 & 5 & 6 & 4 & 5 & 6 \\
\hline & & & \multicolumn{3}{|c|}{ L.S.D. $5 \% 11$} & \multicolumn{3}{|c|}{ L.S.D. $5 \% 6$} \\
\hline \multirow[t]{4}{*}{ July } & $9-10$ & $0-1$ & 3 & 4 & 4 & 4 & 4 & 4 \\
\hline & & $1-2$ & 3 & 4 & 7 & 4 & 5 & 4 \\
\hline & & $2-3$ & 4 & 4 & 9 & 4 & 5 & 4 \\
\hline & & & \multicolumn{3}{|c|}{ L.S.D. $5 \% 2$} & \multicolumn{3}{|c|}{ L.S.D. $5 \% 1$} \\
\hline
\end{tabular}

that the soil of trial V 1 was unable to fix ammonium nitrogen, and also the soil of trial V 2 showed only a low fixing capacity, about $60 \mathrm{ppm}$, of ammonium nitrogen.

At first sampling, in the two surface inches a higher content of nitrate nitrogen was found in the treated plots as compared with those of the untreated ones. At later samplings, only the top inch showed the effect of the nitrogen dressing. Even at the last reported sampling in the beginning of July which occurred after the heavy rains, the effect of fertilizers may be detected in the top layer. The depletion of the lower layers is most likely due to the uptake of nitrogen by the plant roots. It may also be possible that the decrease of the nitrogen content of the top layer at least partly resulted from the assimilation of nitrogen by roots grown into this layer, and not only from the washing down of nitrate ions.

In trial $\mathrm{K} 5$ the plots treated with ammonium nitrate limestone received into the surface inch amounts of ammonium and nitrate nitrogen corresponding to 40 , 80,120 , or $160 \mathrm{ppm}$. Data in Table 8 show that the content of nitrate nitrogen in the two top inches at first sampling exceeds that of the untreated plot by about $30,70,100$, or $130 \mathrm{ppm}$, respectively. This means that a very high part of the fer- 
Table 5. $\mathrm{NH}_{4}-\mathrm{N}$ and $\mathrm{NO}_{3}-\mathrm{N}$ in the soil of trial $\mathrm{V} 1$ treated with ammonium nitrate limestone

\begin{tabular}{|c|c|c|c|c|c|c|c|c|}
\hline & & \multirow{2}{*}{$\begin{array}{l}\text { Depth } \\
\text { (inches) }\end{array}$} & \multicolumn{3}{|c|}{$\mathrm{NH}_{4}-\mathrm{N}$ ppm } & \multicolumn{3}{|c|}{$\mathrm{NO}_{3}-\mathrm{N}$ ppm } \\
\hline \multicolumn{2}{|c|}{ Date } & & 0 & $\mathrm{~N}$ & $2 \mathrm{~N}$ & 0 & $\mathrm{~N}$ & $2 \mathrm{~N}$ \\
\hline \multirow[t]{6}{*}{ May 1} & 11 & $0-1$ & 12 & 75 & 146 & 11 & 54 & 106 \\
\hline & & $1-2$ & 11 & 22 & 32 & 9 & 25 & 46 \\
\hline & & $2-3$ & 11 & 14 & 14 & 9 & 13 & 15 \\
\hline & & $3-4$ & 12 & 13 & 13 & 10 & 10 & 11 \\
\hline & & $4-6$ & 11 & 11 & 14 & 11 & 12 & 13 \\
\hline & & & \multicolumn{3}{|c|}{ L.S.D. $5 \% 15$} & \multicolumn{3}{|c|}{ L.S.D. $5 \% 21$} \\
\hline \multirow{6}{*}{\multicolumn{2}{|c|}{ May 25}} & $0-1$ & 14 & 51 & 103 & 15 & 64 & 124 \\
\hline & & $1-2$ & 12 & 13 & 17 & 6 & 7 & 10 \\
\hline & & $2-3$ & 12 & 12 & 15 & 6 & 7 & 9 \\
\hline & & $3-4$ & 12 & 13 & 11 & 8 & 9 & 9 \\
\hline & & $4-6$ & 12 & 14 & 13 & 11 & 12 & 12 \\
\hline & & & \multicolumn{3}{|c|}{ L.S.D. $5 \% 7$} & \multicolumn{3}{|c|}{ L.S.D. $5 \% 27$} \\
\hline \multirow{4}{*}{\multicolumn{2}{|c|}{ June }} & $0-1$ & 17 & 55 & 91 & 8 & 25 & 65 \\
\hline & & $1-2$ & 15 & 18 & 24 & 4 & 7 & 11 \\
\hline & & $2-3$ & 15 & 26 & 24 & 4 & 5 & 5 \\
\hline & & & \multicolumn{3}{|c|}{ L.S.D. $5 \% 14$} & \multicolumn{3}{|c|}{ L.S.D. $5 \% 8$} \\
\hline \multirow{4}{*}{\multicolumn{2}{|c|}{ June 22}} & $0-1$ & 9 & 50 & 55 & 7 & 21 & 37 \\
\hline & & $1-2$ & 5 & 12 & 6 & 5 & 7 & 8 \\
\hline & & $2-3$ & 6 & 8 & 3 & 6 & 6 & 5 \\
\hline & & & \multicolumn{3}{|c|}{ L.S.D. $5 \% 9$} & \multicolumn{3}{|c|}{ L.S.D. $5 \% 15$} \\
\hline \multirow{4}{*}{\multicolumn{2}{|c|}{ July }} & $0-1$ & 8 & 11 & 15 & 5 & 6 & 11 \\
\hline & & $1-2$ & 7 & 11 & 10 & 5 & 5 & 6 \\
\hline & & $2-3$ & 8 & 11 & 9 & 5 & 5 & 6 \\
\hline & & & \multicolumn{3}{|c|}{ L.S.D. $5 \% 7$} & \multicolumn{3}{|c|}{ L.S.D. $5 \% 2$} \\
\hline
\end{tabular}


Table 6. $\mathrm{NH}_{4}-\mathrm{N}$ and $\mathrm{NO}_{3}-\mathrm{N}$ in the soil of trial $\mathrm{V} 2$ treated with ammonium nitrate limestone

\begin{tabular}{|c|c|c|c|c|c|c|c|c|}
\hline \multirow{2}{*}{\multicolumn{2}{|c|}{ Date }} & \multirow{2}{*}{$\begin{array}{l}\text { Depth } \\
\text { (inches) }\end{array}$} & \multicolumn{3}{|c|}{$\mathrm{NH}_{4}-\mathrm{N}$ ppm } & \multicolumn{3}{|c|}{$\mathrm{NO}_{3}-\mathrm{N}$ ppm } \\
\hline & & & 0 & $\mathrm{~N}$ & $2 \mathrm{~N}$ & 0 & $\mathrm{~N}$ & $2 \mathrm{~N}$ \\
\hline \multirow[t]{6}{*}{ May 1} & 12 & $0-1$ & 13 & 53 & 96 & 13 & 47 & 98 \\
\hline & & $1-2$ & 17 & 13 & 29 & 9 & 19 & 32 \\
\hline & & $2-3$ & 16 & 18 & 18 & 8 & 11 & 14 \\
\hline & & $3-4$ & 15 & 16 & 18 & 9 & 10 & 13 \\
\hline & & $4-6$ & 15 & 17 & 17 & 10 & 12 & 14 \\
\hline & & & \multicolumn{3}{|c|}{ L.S.D. $5 \% 13$} & \multicolumn{3}{|c|}{ L.S.D. $5 \% 13$} \\
\hline \multirow[t]{6}{*}{ May 2} & 26 & $0-1$ & 20 & 50 & 69 & 15 & 54 & 82 \\
\hline & & $1-2$ & 15 & 15 & 17 & 8 & 10 & 12 \\
\hline & & $2-3$ & 14 & 15 & 22 & 8 & 7 & 8 \\
\hline & & $3-4$ & 15 & 17 & 23 & 8 & 8 & 12 \\
\hline & & $4-6$ & 14 & 15 & 15 & 10 & 10 & 13 \\
\hline & & & \multicolumn{3}{|c|}{ L.S.D. $5 \% 8$} & \multicolumn{3}{|c|}{ L.S.D. $5 \% 10$} \\
\hline \multirow{4}{*}{\multicolumn{2}{|c|}{ June }} & $0-1$ & 26 & 59 & 86 & 9 & 22 & 47 \\
\hline & & $1-2$ & 25 & 30 & 27 & 6 & 6 & 13 \\
\hline & & $2-3$ & 26 & 35 & 27 & 5 & 5 & 6 \\
\hline & & & \multicolumn{3}{|c|}{ L.S.D. $5 \% 11$} & \multicolumn{3}{|c|}{ L.S.D. $5 \% 14$} \\
\hline \multirow{4}{*}{\multicolumn{2}{|c|}{ June 23}} & $0-1$ & 12 & 37 & 53 & 8 & 27 & 33 \\
\hline & & $1-2$ & 12 & 9 & 16 & 5 & 5 & 7 \\
\hline & & $2-3$ & 12 & 11 & 10 & 5 & 5 & 5 \\
\hline & & & \multicolumn{3}{|c|}{ L.S.D. $5 \% 7$} & \multicolumn{3}{|c|}{ L.S.D. $5 \% 10$} \\
\hline \multirow{4}{*}{\multicolumn{2}{|c|}{ July }} & $0-1$ & 8 & 17 & 22 & 5 & 6 & 9 \\
\hline & & $1-2$ & 8 & 10 & 14 & 5 & 5 & 8 \\
\hline & & $2-3$ & 8 & 12 & 10 & 5 & 6 & 5 \\
\hline & & & \multicolumn{3}{|c|}{ L.S.D. $5 \% 11$} & \multicolumn{3}{|c|}{ L.S.D. $5 \% 3$} \\
\hline
\end{tabular}


Table 7. $\mathrm{NO}_{3}-\mathrm{N}$ in the soils of trial $\mathrm{V} 1$ and $\mathrm{V} 2$ treated with calcium nitrate

\begin{tabular}{|c|c|c|c|c|c|c|c|}
\hline \multirow[b]{2}{*}{ Date } & \multirow{2}{*}{$\begin{array}{r}\text { Depth } \\
\text { (inches) }\end{array}$} & \multicolumn{3}{|c|}{ V 1} & \multicolumn{3}{|c|}{ V 2} \\
\hline & & 0 & $\mathrm{~N}$ & $2 \mathrm{~N}$ & 0 & $\mathrm{~N}$ & $2 \mathrm{~N}$ \\
\hline May $11-12$ & $0-1$ & 11 & 86 & 205 & 13 & 96 & 182 \\
\hline & $1-2$ & 9 & 40 & 79 & 9 & 34 & 50 \\
\hline & $2-3$ & 9 & 15 & 24 & 8 & 16 & 21 \\
\hline & $3-4$ & 10 & 10 & 12 & 9 & 12 & 14 \\
\hline & $4-6$ & 11 & 13 & 19 & 10 & 12 & 13 \\
\hline & & \multicolumn{3}{|c|}{ L.S.D. $5 \% 21$} & \multicolumn{3}{|c|}{ L.S.D. $5 \% 13$} \\
\hline May $25-26$ & $0-1$ & 15 & 121 & 242 & 15 & 100 & 195 \\
\hline & $1-2$ & 6 & 11 & 14 & 8 & 10 & 13 \\
\hline & $2-3$ & 6 & 7 & 8 & 8 & 8 & 7 \\
\hline & $3-4$ & 8 & 8 & 10 & 8 & 8 & 8 \\
\hline & $4-6$ & 11 & 12 & 12 & 10 & 10 & 12 \\
\hline & & \multicolumn{3}{|c|}{ L.S.D. $5 \% 27$} & \multicolumn{3}{|c|}{ L.S.D. $5 \% 10$} \\
\hline \multirow[t]{4}{*}{ June } & $0-1$ & 8 & 47 & 117 & 9 & 31 & 101 \\
\hline & $1-2$ & 4 & 9 & 24 & 6 & 6 & 17 \\
\hline & $2-3$ & 4 & 4 & 6 & 5 & 6 & 6 \\
\hline & & \multicolumn{3}{|c|}{ L.S.D. $5 \% 8$} & \multicolumn{3}{|c|}{ L.S.D. $5 \% 14$} \\
\hline \multirow[t]{4}{*}{ June $22-23$} & $0-1$ & 7 & 18 & 103 & 8 & 42 & 101 \\
\hline & $1-2$ & 5 & 7 & 21 & 5 & 7 & 19 \\
\hline & $2-3$ & 6 & 6 & 6 & 5 & 5 & 6 \\
\hline & & \multicolumn{3}{|c|}{ L.S.D. $5 \% 15$} & \multicolumn{3}{|c|}{ L.S.D. $5 \% 10$} \\
\hline \multirow[t]{4}{*}{ July } & $0-1$ & 5 & 6 & 6 & 5 & 5 & 13 \\
\hline & $1-2$ & 5 & 5 & 5 & 5 & 5 & 10 \\
\hline & $2-3$ & 5 & 5 & 5 & 5 & 5 & 6 \\
\hline & & \multicolumn{3}{|c|}{ L.S.D. $5 \% 2$} & \multicolumn{3}{|c|}{ L.S.D. $5 \% 3$} \\
\hline
\end{tabular}


Table 8. $\mathrm{NH}_{4}-\mathrm{N}$ and $\mathrm{NO}_{3}-\mathrm{N}$ in the soil of trial $\mathrm{K} 5$ treated with ammonium nitrate limestone

\begin{tabular}{|c|c|c|c|c|c|c|c|c|c|c|c|c|}
\hline \multirow{2}{*}{\multicolumn{2}{|c|}{ Date }} & \multirow{2}{*}{$\begin{array}{l}\text { Depth } \\
\text { (inches) }\end{array}$} & \multicolumn{5}{|c|}{$\mathrm{NH}_{4}-\mathrm{N}$ ppm } & \multicolumn{5}{|c|}{$\mathrm{NO}_{3}-\mathrm{N}$ ppm } \\
\hline & & & 0 & $\mathbf{N}$ & $2 \mathrm{~N}$ & $3 \mathrm{~N}$ & $4 \mathrm{~N}$ & 0 & $\mathbf{N}$ & $2 \mathrm{~N}$ & $3 \mathrm{~N}$ & $4 \mathrm{~N}$ \\
\hline \multirow[t]{6}{*}{ June } & 9 & $0-1$ & 8 & 12 & 30 & 42 & 60 & 15 & 28 & 44 & 45 & 61 \\
\hline & & $1-2$ & 3 & 4 & 3 & 6 & 4 & 13 & 28 & 58 & 80 & 95 \\
\hline & & $2-3$ & 3 & 4 & 4 & 2 & 4 & 18 & 11 & 16 & 18 & 19 \\
\hline & & $3-4$ & 4 & 4 & 4 & 1 & 2 & 10 & 10 & 11 & 12 & 11 \\
\hline & & $4-6$ & 4 & 3 & 3 & 3 & 3 & 10 & 11 & 11 & 12 & 11 \\
\hline & & & \multicolumn{5}{|c|}{ L.S.D. $5 \% 7$} & \multicolumn{5}{|c|}{ L.S.D. $5 \% 9$} \\
\hline \multirow[t]{6}{*}{ June : } & 23 & $0-1$ & 7 & 7 & 12 & 12 & 23 & 6 & 9 & 16 & 26 & 40 \\
\hline & & $1-2$ & 7 & 6 & 5 & 4 & 6 & 5 & 6 & 9 & 13 & 37 \\
\hline & & $2-3$ & 5 & 5 & 4 & 7 & 6 & 4 & 6 & 9 & 12 & 31 \\
\hline & & $3-4$ & 5 & 5 & 5 & 5 & 4 & 5 & 7 & 8 & 8 & 17 \\
\hline & & $4-6$ & 5 & 3 & 4 & 5 & 3 & 5 & 6 & 10 & 8 & 9 \\
\hline & & & \multicolumn{5}{|c|}{ L.S.D. $5 \% 5$} & \multicolumn{5}{|c|}{ L.S.D. $5 \% 7$} \\
\hline \multirow[t]{5}{*}{ July } & 7 & $0-1$ & 7 & 6 & 9 & 10 & 10 & 4 & 3 & 5 & 6 & 7 \\
\hline & & $1-2$ & 6 & 6 & 7 & 7 & 7 & 3 & 3 & 4 & 4 & 5 \\
\hline & & $2-3$ & 8 & 5 & 6 & 5 & 7 & 4 & 3 & 4 & 4 & 6 \\
\hline & & $3-4$ & 5 & 5 & 7 & 6 & 6 & 4 & 4 & 4 & 4 & 6 \\
\hline & & & \multicolumn{5}{|c|}{ L.S.D. $5 \% 3$} & \multicolumn{5}{|c|}{ L.S.D. $5 \% 2$} \\
\hline
\end{tabular}

tilizer nitrate applied was recovered from these layers. On the other hand, only about one third or even less of the ammonium nitrogen applied is recovered by this extraction. It was found (4) that at this sampling date no differences existed between the amounts of nitrogen taken up by the plants from the plots with various treatments. Thus, it may be supposed that the low recovery of ammonium nitrogen is largely due to the fixation of ammonium ions in this soil. Its ammonium fixation capacity was found to be about $200 \mathrm{ppm}$.

The nitrate nitrogen of the ammonium nitrate limestone and calcium nitrate (Table 9) was accumulated particularly in the layer from 1 to 2 inches and in the top inch. The higher applications of calcium nitrate also slightly increased the nitrate nitrogen content of the layer from 2 to 3 inches. Probably owing to the wet period in the middle of June, no accumulation of nitrate nitrogen in the top inch of the soil treated with calcium nitrate may be detected at second sampling in June. In the soil treated with ammonium nitrate limestone, however, the top inch appears to be the richest in nitrate nitrogen. An explanation for this might be found in the possible slow nitrification of the ammonium ions in the top layer, this nitrification occurring more rapidly than the downwards movement of the nitrate ions.

In the beginning of July, no indication of the presence of fertilizer nitrogen in any of the layers can be found. The same holds true also with later samplings the results of which are not reported here. 
Table 9. $\mathrm{NO}_{3}-\mathrm{N}$ in the soil of trial $\mathrm{K} 5$ treated with calcium nitrate

\begin{tabular}{|c|c|c|c|c|c|c|c|}
\hline \multirow{2}{*}{\multicolumn{2}{|c|}{ Date }} & \multirow{2}{*}{$\begin{array}{l}\text { Depth } \\
\text { (inches) }\end{array}$} & \multicolumn{5}{|c|}{$\mathrm{NO}_{3}-\mathrm{N}$ ppm } \\
\hline & & & 0 & $\mathrm{~N}$ & $2 \mathrm{~N}$ & $3 N$ & $4 \mathrm{~N}$ \\
\hline \multirow[t]{6}{*}{ June } & 9 & $0-1$ & 15 & 36 & 49 & 84 & 107 \\
\hline & & $1-2$ & 13 & 52 & 86 & 139 & 205 \\
\hline & & $2-3$ & 8 & 13 & 19 & 36 & 38 \\
\hline & & $3-4$ & 10 & 10 & 12 & 13 & 13 \\
\hline & & $4-6$ & 10 & 9 & 11 & 11 & 11 \\
\hline & & & \multicolumn{5}{|c|}{ L.S.D. $5 \% 12$} \\
\hline \multirow[t]{6}{*}{ June } & 23 & $0-1$ & 6 & 8 & 10 & 22 & 25 \\
\hline & & $1-2$ & 5 & 7 & 11 & 33 & 38 \\
\hline & & $2-3$ & 4 & 6 & 10 & 32 & 39 \\
\hline & & $3-4$ & 5 & 6 & 8 & 22 & 30 \\
\hline & & $4-6$ & 5 & 6 & 8 & 14 & 18 \\
\hline & & & \multicolumn{5}{|c|}{ L.S.D. $5 \% 7$} \\
\hline \multirow[t]{6}{*}{ July } & 7 & $0-1$ & 4 & 3 & 4 & 5 & 6 \\
\hline & & $1-2$ & 3 & 3 & 3 & 4 & 6 \\
\hline & & $2-3$ & 4 & 4 & 3 & 4 & 10 \\
\hline & & $3-4$ & 4 & 4 & 3 & 4 & 11 \\
\hline & & $4-6$ & 4 & 4 & 3 & 4 & 7 \\
\hline & & & \multicolumn{5}{|c|}{ L.S.D. $5 \% 3$} \\
\hline
\end{tabular}

In trial $\mathrm{V} 4$ the distribution of ammonium and nitrate nitrogen both in noncropped and cropped plots was followed. The results for the plots treated with calcium nitrate are reported in Table 10. The first sampling does not yet show any difference between the non-cropped and cropped soils. The nitrate nitrogen applied is mainly recovered by the extraction of the samples from the top inch. The nitrate content of this layer in the cropped plots did not markedly change during the following period of two weeks within which there was only very little rain. The results at the sampling in the end of June, or after a wetter period, indicate a marked decrease in the nitrate nitrogen content of the top inch of the cropped soil and some increase in the nitrate nitrogen content of the second layer. At this time, also a distinct difference exists between the values for the non-cropped and the cropped soils, the former being in all layers significantly higher than the corresponding latter ones.

Even at the last sampling reported here, the nitrate nitrogen content of the top inch of the non-cropped soil is quite marked in spite of the heavy rains occurring in June and the first part of July. It may be calculated that eight weeks from starting the trial the amounts of nitrate nitrogen in the top inch of the variously treated plots of this non-cropped soil correspond to about 50-60 per cent of the 
Table 10. $\mathrm{NO}_{3}-\mathrm{N}$ in the soil of trial $\mathrm{V} 4$ treated with calcium nitrate (non-cropped $=-$, cropped soil $=+$ )

\begin{tabular}{|c|c|c|c|c|c|c|c|c|c|c|}
\hline \multirow{3}{*}{ Date } & \multirow{3}{*}{$\begin{array}{r}\text { Depth } \\
\text { (inches) }\end{array}$} & \multicolumn{9}{|c|}{$\mathrm{NO}_{3}-\mathrm{N}$ ppm } \\
\hline & & \multicolumn{2}{|c|}{0} & \multicolumn{2}{|c|}{$2 \mathrm{~N}$} & \multicolumn{2}{|c|}{$3 \mathrm{~N}$} & \multicolumn{2}{|c|}{$4 \mathrm{~N}$} & \multirow{2}{*}{$\begin{array}{c}\text { L.S.D. } \\
5 \%\end{array}$} \\
\hline & & - & + & - & + & - & + & - & + & \\
\hline \multirow[t]{6}{*}{ May 31} & $0-1$ & 15 & 11 & 125 & 171 & 197 & 218 & 286 & 311 & 78 \\
\hline & $1-2$ & 13 & 9 & 14 & 16 & 19 & 20 & 26 & 30 & 9 \\
\hline & $2-3$ & 12 & 9 & 11 & 11 & 11 & 11 & 19 & 18 & 8 \\
\hline & $3-4$ & 13 & 12 & 10 & 11 & 12 & 10 & 14 & 10 & 3 \\
\hline & $4-6$ & 13 & 11 & 14 & 20 & 15 & 27 & 25 & 25 & 9 \\
\hline & & & & & & & & & & 35 \\
\hline \multirow[t]{6}{*}{ June 13} & $0-1$ & & 12 & & 176 & & 210 & & 284 & 91 \\
\hline & $1-2$ & & 7 & & 12 & & 11 & & 13 & 4 \\
\hline & $2-3$ & & 6 & & 9 & & 6 & & 8 & 3 \\
\hline & $3-4$ & & 6 & & 6 & & 6 & & 6 & 2 \\
\hline & $4-6$ & & 8 & & 11 & & 12 & & 11 & 4 \\
\hline & & & & & & & & & & 38 \\
\hline \multirow[t]{6}{*}{ June 27} & $0-1$ & 25 & 4 & 154 & 55 & 230 & 154 & 299 & 164 & 75 \\
\hline & $1-2$ & 15 & 3 & 64 & 15 & 82 & 68 & 90 & 63 & 33 \\
\hline & $2-3$ & 13 & 3 & 36 & 5 & 30 & 9 & 41 & 7 & 14 \\
\hline & $3-4$ & 14 & 3 & 22 & 3 & 20 & 8 & 33 & 6 & 8 \\
\hline & $4-6$ & 17 & 3 & 27 & 7 & 31 & 10 & 38 & 8 & 11 \\
\hline & & & & & & & & & & 37 \\
\hline \multirow[t]{6}{*}{ July 12} & $0-1$ & 20 & 7 & 125 & 13 & 187 & 13 & 263 & 30 & 46 \\
\hline & $1-2$ & 7 & 6 & 19 & 9 & 31 & 12 & 36 & 22 & 13 \\
\hline & $2-3$ & 8 & 6 & 17 & 7 & 22 & 7 & 24 & 11 & 6 \\
\hline & $3-4$ & 11 & 6 & 17 & 7 & 20 & 6 & 21 & 8 & 4 \\
\hline & $4-6$ & 13 & 7 & 28 & 7 & 28 & 7 & 39 & 9 & 11 \\
\hline & & & & & & & & & & 22 \\
\hline
\end{tabular}

quantities applied as calcium nitrate. In all the six inches amounts corresponding to about $70-80$ per cent of the nitrate nitrogen in the fertilizer are recovered. The amounts recovered at first sampling were not higher.

It is likely that in this soil, fairly rich in organic matter, the mobilization of organic nitrogen is not insignificant. Thus the losses of nitrate nitrogen from the top six inches probably are markedly higher than about $20-30$ per cent. Both the leaching of nitrogen into lower layers and denitrification may play their role in these losses.

It may be of interest to note that in the soils treated with calcium nitrate also the effect of the ammonium nitrogen in this fertilizer could be detected. The ammonium nitrogen content of the top inch of the non-cropped soil was at the different samplings as follows: 


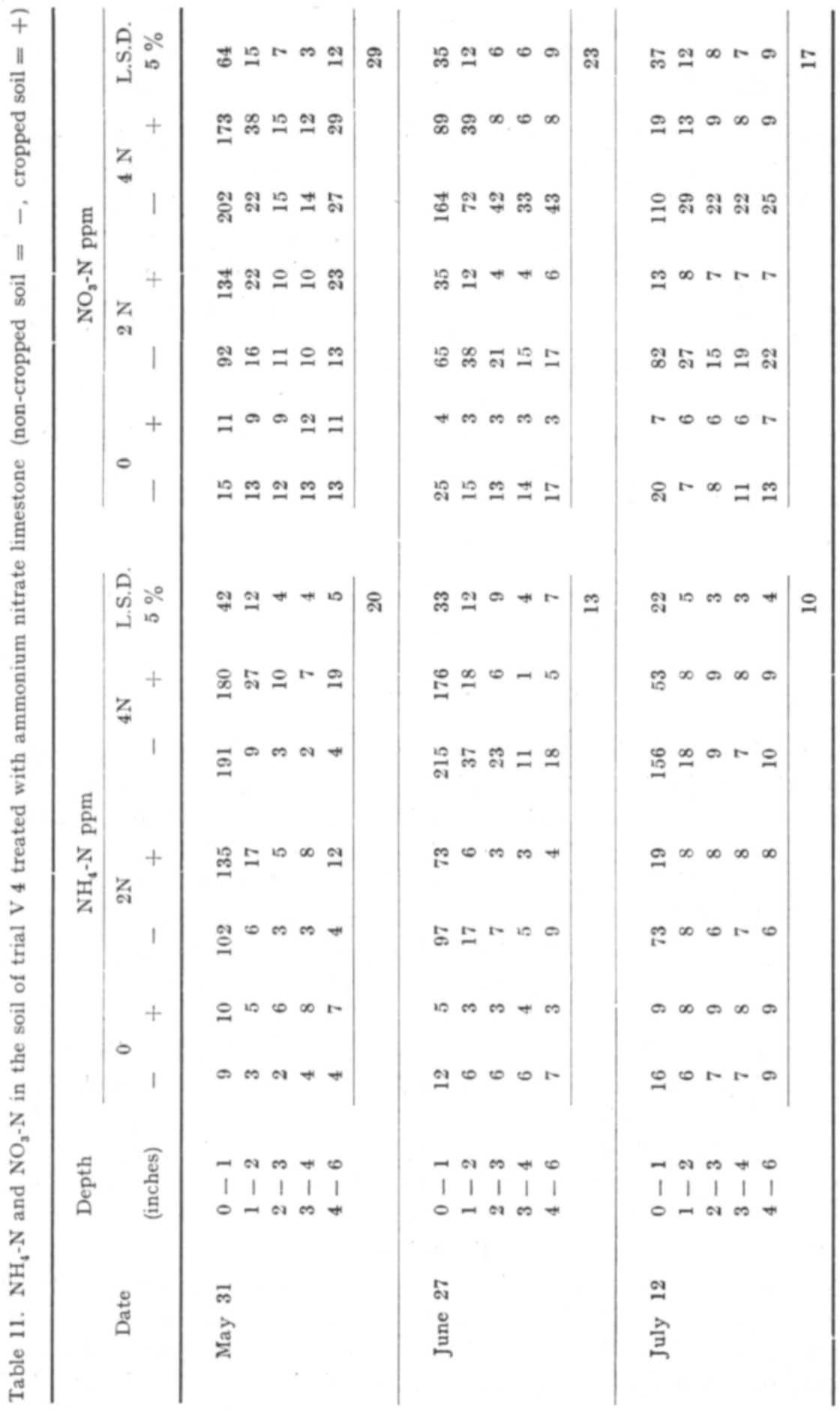




$\begin{array}{crcccc}\mathrm{NH}_{4}-\mathrm{N} \text { ppm } & 0 & 2 \mathrm{~N} & 3 \mathrm{~N} & 4 \mathrm{~N} & \text { L.S.D. } 5 \% \\ \text { May } 31 & 9 & 22 & 26 & 37 & 8 \\ \text { June } 27 & 12 & 35 & 45 & 54 & 14 \\ \text { July } 12 & 16 & 29 & 39 & 47 & 16\end{array}$

The ammonium nitrogen applied in ammonium nitrate limestone was for the most part recovered from the top inch of first sampling (Table 11), although the heaviest dressing had also caused some increase in the ammonium nitrogen content of the following layer. This soil did not to any marked degree fix ammonium ion. Particularly in the non-cropped soil, no decrease in the ammonium nitrogen content occurred during the period of four weeks. At the sampling of June 27 the noncropped soil treated with the heaviest amount of fertilizer contained in most layers significantly more ammonium nitrogen than the corresponding cropped soil.

The decrease in the ammonium nitrogen content of the non-cropped soil was not compensated by a corresponding increase in the content of nitrate nitrogen during the period from June 27 to July 12 . The loss of nitrogen is of about the same order as that found for the soil treated with calcium nitrate. Also the possible reasons for these losses are the same, leaching or denitrification.

The nitrate nitrogen content of the different layers in the soil treated with ammonium nitrate limestone, shows the same features as was observed for the treatment with calcium nitrate.

\section{Discussion}

The results reported in the present paper indicate that not only ammonium nitrogen but also nitrate nitrogen applied as a surface dressing may for a considerable period remain in the surface inch, provided no heavy rainfalls or longer periods of moderate rain occur soon after the application of the fertilizers. Thus these results are in accordance with the findings of some other workers $(1,2,7)$. The plants were able to deplete the layers below the surface inch fairly rapidly, but even after six and eight weeks from sowing the top inch of the treated plots might contain considerably more ammonium and nitrate nitrogen than the top inch of the untreated plots.

Since in Finland May and June are often particularly dry the nitrogen fertilizers broadcasted on the surface may not be utilized as effectively as could be the case if the available nitrogen had been distributed in the layers where the plant roots are able to assimilate it. Therefore, placement or working in of nitrogen fertilizers may be profitable. In every case, this is a possibility worth of further study.

Some indication of the fixation of ammonium nitrogen as unexchangeable forms was observed. In the trials the soil of which is known to have a marked capacity to fix ammonium ions, the amount of ammonium nitrogen extracted by potassium sulphate was distinctly lower than in trials where the soil has a low fixing capacity. That fixation did not in the present cases significantly impair the availability of ammonium nitrogen may be concluded from the fact that the oats yields produced by ammonium nitrate limestone were not lower than those produced by an equal amount of nitrogen as calcium nitrate (cf. 4). 
It seems probable that later in the growing period the plants are able to produce roots also in the surface layer of soil and take up nitrogen from it, provided it is not quite dry. In the present study, at least, the ammonium nitrogen and nitrate nitrogen content of the top inch of the non-cropped soil were markedly higher than the corresponding values for the cropped soil, e.g. six weeks after the application of the fertilizers.

\section{$S u m m$ ary}

The distribution of ammonium nitrogen and nitrate nitrogen in the soils of field trials was followed in two growing seasons. In these trials ammonium nitrate limestone and calcium nitrate were, at several rates, applied as surface dressing.

It was found that not only the ammonium nitrogen but also the nitrate nitrogen applied to the surface of loam, silt, silt clay, and fine sand clay soils tended to remain in the top inch for a considerable period in the absence of heavy rainfalls or a longer wet period. The plants appeared rapidly to deplete the layers downwards from 1 inch, but even after six and eight weeks from the application of the fertilizers the ammonium nitrogen and nitrate nitrogen contents of the surface inch could be markedly higher in the treated plots than in the untreated ones. In the noncropped soil, eight weeks after the application of the fertilizers, the mineral nitrogen content of the top inch corresponded to about $60 \%$ of the nitrogen applied.

On the basis of these results the working in or placement of nitrogen fertilizers seems to be profitable.

Fixation of ammonium nitrogen in unexchangeable forms was observed in some of the trials. This, however, did not significantly impair the value of ammonium nitrate limestone as a nitrogen source in these trials.

Acknowledgement. The authors wish to express their gratitude to Prof. Dr. P. Schachtschabel of Hannover for his advice concerning the method for the determination of the ammonium fixing capacity of the soil.

\section{REFERENCES:}

(1) Cunningham, R. K. \& Cooke, G. W. 1958. Soil nitrogen. II. - Changes in levels of inorganic nitrogen in a clay-loam soil caused by fertilizer additions, by leaching and uptake by grass. J. Sci. Fd. Agric. 9: 317-324.

(2) GASSER, J. K. R. 1959. Soil nitrogen IV. - Transformations and movement of fertilizer nitrogen in a light soil. Ibid. 10: 192-197.

(3) Heinonen, R. 1960. A soil core sampler with provision for cutting successive layers. J. Sci Agric. Soc. Finland 32: 176-178. 
(4) Hänninen, P. \& KAILA, A. 1961. Calcium nitrate and ammonium nitrate limestone as the source of nitrogen for oats. Ibid 33: 159-168.

(5) Lyndersen, D. L. \& OPEM, M. 1958. Zur Wasserdampfdestillation von Ammoniak aus Bodenextrakten. Z. anal. Chem. 159: 339-343.

(6) Ронjanheimo, O. \& Heinonen, R. 1960. The effect of irrigation on root development, water use, nitrogen uptake and yield characteristics of several barley varietes. Acta Agr. Fennica $95,6$.

(7) Stewart, B. A. \& Eck, H. V. 1958. Movement of surface-applied nitrate into soils at five moisture levels. Soil Sci. Soc. Amer. Proc. 22: 260-262.

S E L O T U S :

LANNOITETYPEN KULKEUTUMISESTA MAASSA

ARMI KAILA

Yliopiston maanviljelyskemian laitos, Helsinki

Pentti Hänninen

Maatalouden tutkimuskeskus, Keski-Suomen koeasema, Kuusa

Tutkimuksessa on seurattu lannoitteiden ammonium- ja nitraattitypen kulkeutumista ja muutoksia maassa analysoimalla kahden kasvukauden aikana säännöllisin väliajoin otettuja kenttäkokeiden maanäytteitä. Kokeissa käytettiin kalkkisalpietaria ja oulunsalpietaria pintalannoituksena. Koekasvina oli kaura. Todettiin, ettei vain ammoniumtyppi vaan myös nitraattityppi pyrki jäämään ylimpään tuuman paksuiseen kerrokseen, ellei sattunut kovia sateita tai pitkähköä kosteata jaksoa. Kasvit näyttivät verraten nopeasti käyttävän typen tuumaa syvemmistä kerroksista, mutta vielä $11 / 2-2$ kuukauden kuluttua kokeitten kylvöstä ja lannoituksesta saattoi lannoitettujen koeruutujen pintakerroksessa olla varsin runsaasti sekä ammonium- että etenkin nitraattityppeä. Kesantoruuduilla vastasi pintakerroksen typenpitoisuus vielä heinäkuun puolivälissä noin $60 \%$ lannoituksena annetusta nitraattitypestä.

Tulosten perusteella näyttää siltä, että etenkin kevätkuivuudesta usein kärsivăssä lounaisSuomessa saattaisi olla syytä harkita myös typpilannoitteiden multausta ellei varsinaista sijoituslannoitusta voida suorittaa.

Eräissä koemaissa voitiin todeta ammoniumtypen pidättymistä vaihtumattomaksi. Se ei kuitenkaan näyttänyt sanottavasti heikentävän oulunsalpietarin tehokkuutta kauran typpilannoitteena näissä kokeissa. 